\title{
The Students' Responses on the Implementation of Student-Made Video Project in ESP Classroom to Train $21^{\text {st }}$ Century Skills
}

\author{
Adelia Puspa and Syahrial \\ Universitas Bengkulu \\ Bengkulu, Indonesia \\ adelia.puspa@gmail.com \\ eric.syahrial@gmail.com
}

\begin{abstract}
English mastery and 21st century skills are two important considerations for every educator as education is striving to prepare today's students to become prepared for the competitive global market of tomorrow. In the previous study, the researcher had implemented student-made video project to develop students' English. Having observed the students' English skills development in each phase of student-made video project, in this further study the researcher investigated the students' responses of English for Management class toward the project. The points cover in the students' responses are in relevance to $21^{\text {st }}$ century skills, which are the students' responses toward autonomy in learning English, the students' responses toward teamwork, and the students' responses toward technology used in English learning environment. The data was obtained through questionnaires and interview. The result revealed that despite the students' difficulties in running the project, they responded positively to the project. However, even though students realize the benefit of the video project related to the development of $21^{\text {st }}$ century skills, the statements and high average score from the questionnaire do not suffice, as it can be argued that the students of the responses might be due to their awareness that the project must be useful. It is important, therefore, to scrutinize further what the students associated with their positive attitudes as they answered the questions for this research, which will in turn lead to the knowledge of important factors to students' learning motivation.
\end{abstract}

Keywords—students' responses; student-made video project; ESP classroom project; $21^{\text {st }}$ century skills

\section{INTRODUCTION}

Since January 2016, ASEAN Economic Community had been effectively applied, and companies are preparing themselves to compete globally among ASEAN nations. As a result, some national and International companies have applied the mastery of English skills and 21st century skills as basic requirements for recruiting new workers. According to Partnership for 21st Century Skills (2009), the 21st century skills are the skills, knowledge and expertise that students should master to succeed in work and life. According to the en Gauge NCREL (2003), 21st century skills consist of digital age literacy skills, inventive thinking which includes knowledge creation, self-directed, and collaborative work [1]. As English mastery and 21st century skills are now two important considerations for selecting the workforce candidates, it becomes educators' duty to reconsider how they approach learning, instruction, and environment to prepare the students to meet these challenges.

The best way to help students to master English skills and 21 st century skills is to enhance their learning experience. Based on Hidden Curriculum (2014) learning experience refers to any interaction, course, program, or other experience in which learning takes place, whether it occurs in traditional academic settings or nontraditional settings, or whether it includes traditional educational interactions or nontraditional interactions. This wide definition had been narrowed in this study in which the term learning experience is used to reinforce activities of an educational interaction rather than its location (school, classroom) or format (course, program). It is to vary how to teach the students and how the students learn to achieve skills needed to compete in $21 \mathrm{st}$ century.

Technology is a perfect vehicle for facilitating this due to the fact that nowadays, technology influences almost every aspect of people's lives, and technology has become a common tool for the communication of people in business, education, entertainment, and social life. More importantly, technology skills are considered as one of the 21 st century skills that students must possess. But the point is not about learning how to use technology or even teaching with technology tools, it is about students creating and constructing with technology. Hence, such English learning activity with the use of technology should be implemented to foster the students to develop their English skills and 21st century skills.

As a starting point, at Universitas Bengkulu, most classrooms are well equipped with LCD projector, visualizer and internet accessibility. In addition, most of Universitas Bengkulu students have notebook computers, tablets, and smart phones which can connect to the internet. These devices are normally used in English class for looking up vocabulary online and searching for information. The traditional atmosphere in which students sit quietly and listen to the lecturer is a scene from the past that rarely occurs in today's language class.

Unfortunately, at Universitas Bengkulu, English course is only available for the first semester students. So, the students only have six months period of learning English during their college years. It is considered as inadequate to 
cover the ultimate goal of mastering the four English skills. In addition, each English class has 30 to 60 students who have different English language proficiency levels and different learning styles. Due to the large class size and different learning preferences, it is hard for the instructor to pay attention to individual student equally or allow one to practice the English skills sufficiently in a limited class time [2].

To solve this problem successfully, in the previous research the researcher had implemented student-made video project. The result showed that student-made video project is relevant in the language learning. One positive finding is that all the students took part in the project. It support the notion that students-made video project not only trained students' English skills, but it also means that this project can covers the various learners' learning styles. There are three primary modalities through which people take in information: visual, auditory and tactile. These three modalities to how students process information, deriving three basic learning styles: visual-spatial, auditory-sequential and tactile-kinesthetic [3].

To gain deeper information regarding the project, in this study, the researcher discussed the students' response towards the using of student-made video in English for Management class. The responses cover the point of the relevance to development of $21^{\text {st }}$ century skills. The researcher presented both qualitative and quantitative data on the investigated conditions. In the end, the researcher concluded with recommendations for applying student-made video project as a pedagogical technique to train $21^{\text {st }}$ century skills to the students.

\section{METHOD}

The subject of this study was the first semester students of non-English Department of Universitas Bengkulu who took English I course as one of their obligatory courses. The sample of this research was one class of Management students.

Moreover, there were three main instruments used in this research; questionnaire, interview, and group observation checklist and group reports.

\section{Questionnaire}

The designed questionnaires were administered to the subjects of 31 students of Management class. The closedended questionnaires were used to collect the quantitative data. The questionnaire was validated by the experts and piloted before used in the studied class. In order to reach the same understanding, the questionnaire was orally translated into Bahasa Indonesia while being administered to the students in the classroom. For the students' responses, the students were asked to rate the degree of agreement on each item. The rating criteria are five point Likert scales: 5=Strongly Agree; 4=Agree, 3=Neutral (neither agree nor disagree); $2=$ Disagree; $1=$ Strongly Disagree.

The evaluation criteria of the open-ended questionnaire was done by analyzing the mean score by using SPSS version 22. The criteria are as in the table 1:
Table 1. Evaluation Criteria of the Questionnaire

\begin{tabular}{cc}
\hline $1.00-$ & The positive attitude towards the student- \\
1.80 & made video project is very low. \\
\hline $1.81-$ & The positive attitude towards the student- \\
2.60 & made video project is low. \\
\hline $2.61-$ & The positive attitude towards the student- \\
3.20 & made video project is moderate. \\
\hline $3.21-$ & The positive attitude towards the student- \\
4.80 & made video project is high. \\
\hline $4.81-$ & The positive attitude towards the student- \\
5.00 & made video project is very high. \\
\hline
\end{tabular}

\section{Semi-structured Interview}

Interviewing is a common means to collecting qualitative data, involving person to person encounter in which one person elicits information from another. The main purpose of an interview is to obtain a specific kind of information. Interview allows us to find out things that could not directly observe. In this case, in order to gain more indepth data, the interviews were conducted at the end of the course, out of class, and phone-recorded.

1. Group Observation Checklist and Group Reports

The group observation checklist was filled by the groups' leaders who responsible to monitor the project work outside the classroom. Group reports were arranged by each group to see the detailed description of the video production process including the students' activities in each phase, the role of each member, and the difficulties they encountered. The group report should be handed along with the copy of the video.

\section{FINDING AND DISCUSSION}

Having observed the students' English skills development in each phase of student-made video project, and the most developed English skill in the previous research, the researcher investigated the students' response toward the project. The point covers in the students' responses are about the relevance to development of $21^{\text {st }}$ century skills. This point was described based on questionnaire and interview data. Findings

\section{a. Quantitative Data}

In the questionnaire employed for the present research, the questionnaire was divided into three categories; students response in the aspect of autonomy, teamwork, and technology experience. The students' responses were analyzed quantitatively based on the mean score by using SPSS version 22. The responses of Strongly Agree (SA) and Agree (A) were classified as positive response, while the responses of Disagree (D) and Strongly Disagree (SD) were categorized as negative responses. 


\section{1) Students' Responses toward Autonomy}

Ten items were dedicated to student autonomy in the questionnaire. The items were divided into issues concerning independent learning outside the classroom (Items 1, 2, 3, 4, and 6), applying knowledge from classroom (Item 5), increasing student motivation (7), and student dependence on the instructors (item 8 to 10). . It can be seen in the table 2 .

Table 2. Students' Responses toward Autonomy on the Project

\begin{tabular}{|c|c|c|c|c|c|c|c|}
\hline Item & Statement & $\begin{array}{c}\mathrm{SA}, \\
\mathbf{A} \\
\%\end{array}$ & $\begin{array}{l}\mathbf{N} \\
\%\end{array}$ & $\begin{array}{c}\text { D, } \\
\text { SD } \\
\%\end{array}$ & $\begin{array}{l}\text { Me } \\
\text { an }\end{array}$ & $\begin{array}{l}\text { Std. } \\
\text { Dev. }\end{array}$ & $\begin{array}{l}\text { Cate } \\
\text { gory }\end{array}$ \\
\hline 1 & $\begin{array}{l}\text { The video } \\
\text { project } \\
\text { made me } \\
\text { look for } \\
\text { more } \\
\text { knowledge } \\
\text { outside the } \\
\text { classroom. }\end{array}$ & 80.65 & 16.13 & 3.23 & 4.29 & 0.74 & High \\
\hline 2 & $\begin{array}{l}\text { The video } \\
\text { project } \\
\text { helped me } \\
\text { to gain } \\
\text { knowledge } \\
\text { in addition } \\
\text { to what I } \\
\text { learned in } \\
\text { the } \\
\text { classroom. }\end{array}$ & 77.42 & 22.58 & 0.00 & 4.23 & 0.67 & High \\
\hline 3 & $\begin{array}{l}\text { The video } \\
\text { project } \\
\text { helped me } \\
\text { develop } \\
\text { learning } \\
\text { autonomy. }\end{array}$ & 83.87 & 12.90 & 3.23 & 4.45 & 0.57 & High \\
\hline 4 & $\begin{array}{l}\text { The video } \\
\text { project } \\
\text { made me } \\
\text { become } \\
\text { more } \\
\text { responsible } \\
\text { for } \\
\text { studying. }\end{array}$ & 80.65 & 19.35 & 0.00 & 4.29 & 0.64 & High \\
\hline 5 & $\begin{array}{l}\text { I applied the } \\
\text { knowledge } \\
\text { from the } \\
\text { classroom } \\
\text { when I did } \\
\text { the video } \\
\text { project. }\end{array}$ & 70.97 & 25.81 & 3.23 & 4.19 & 0.65 & High \\
\hline
\end{tabular}

Table 2. Cont

\begin{tabular}{|c|c|c|c|c|c|c|c|}
\hline 6 & \begin{tabular}{|l} 
I tried to \\
search for \\
what I \\
wanted to \\
know by \\
myself \\
while \\
working on \\
the video \\
project. \\
\end{tabular} & 87.10 & 16.13 & 0.00 & 4.48 & 0.67 & High \\
\hline 7 & $\begin{array}{l}\text { After } \\
\text { completing } \\
\text { the video } \\
\text { project, I } \\
\text { am } \\
\text { confident } \\
\text { that I can } \\
\text { study } \\
\text { efficiently } \\
\text { outside } \\
\text { classroom } \\
\text { all by } \\
\text { myself. } \\
\end{array}$ & 64.52 & 29.03 & 6.45 & 3.19 & 0.70 & $\begin{array}{l}\text { Mod } \\
\text { erate }\end{array}$ \\
\hline 8 & $\begin{array}{l}\text { I need help } \\
\text { from the } \\
\text { instructors } \\
\text { in some } \\
\text { manner } \\
\text { when } \\
\text { working on } \\
\text { the video } \\
\text { project. }\end{array}$ & 83.87 & 9.68 & 6.45 & 4.36 & 0.71 & High \\
\hline 9 & $\begin{array}{l}\text { I think the } \\
\text { teacher's } \\
\text { advice on } \\
\text { the video } \\
\text { project was } \\
\text { necessary. }\end{array}$ & 74.19 & 19.35 & 6.45 & 4.03 & 0.88 & High \\
\hline 10 & $\begin{array}{l}\text { When there } \\
\text { was a } \\
\text { problem } \\
\text { while doing } \\
\text { the video } \\
\text { project, I } \\
\text { consult my } \\
\text { teacher to } \\
\text { solve. }\end{array}$ & 61.29 & 29.03 & 9.68 & 2.81 & 0.84 & $\begin{array}{l}\text { Mod } \\
\text { erate }\end{array}$ \\
\hline
\end{tabular}

With the exception of the average scores for Item 9, those of all the other items pertaining to autonomy were high, ranging from 2.81 to 4.48 , indicating that the video project had helped in the aforementioned aspects.

\section{2) Students' Response toward Teamwork}

The aspects about teamwork from cooperating for a video project included working with others (Items 11 and 12), 
developing self-confidence (Items 14 and 15), knowledge sharing (Item 13), making a decision (Item 16), solving a problem (Item 17) and evaluating oneself after receiving feedback from others (Items 18). It can be seen in the table 3 .

Table 3. Students' Responses toward Teamwork on the Project

\begin{tabular}{|c|c|c|c|c|c|c|c|}
\hline $\begin{array}{c}\text { Ite } \\
\text { m }\end{array}$ & Statement & $\begin{array}{c}\text { SA, } \\
\text { A } \\
\%\end{array}$ & $\begin{array}{l}\mathbf{N} \\
\%\end{array}$ & $\begin{array}{c}\text { D, SD } \\
\%\end{array}$ & $\begin{array}{c}\text { Me } \\
\text { an }\end{array}$ & $\begin{array}{l}\text { Std. } \\
\text { Dev. }\end{array}$ & $\begin{array}{c}\text { Catego } \\
\text { ry }\end{array}$ \\
\hline 11 & $\begin{array}{l}\text { The video } \\
\text { project } \\
\text { allowed me } \\
\text { to work } \\
\text { with others } \\
\text { as a team. }\end{array}$ & $\begin{array}{r}74.1 \\
9\end{array}$ & 25.81 & 0.00 & $\begin{array}{c}4.0 \\
9\end{array}$ & 0.91 & High \\
\hline 12 & $\begin{array}{c}\text { The video } \\
\text { project } \\
\text { increased } \\
\text { the skill of } \\
\text { cooperating } \\
\text { with others. }\end{array}$ & $\begin{array}{r}80.6 \\
5\end{array}$ & 16.13 & 3.23 & $\begin{array}{c}4.1 \\
9\end{array}$ & 0.70 & High \\
\hline 13 & $\begin{array}{l}\text { The video } \\
\text { project } \\
\text { encouraged } \\
\text { me to } \\
\text { exchange } \\
\text { knowledge } \\
\text { with my } \\
\text { friends. } \\
\end{array}$ & $\begin{array}{r}83.8 \\
7\end{array}$ & 16.13 & 0.00 & $\begin{array}{c}4.3 \\
6\end{array}$ & 0.71 & High \\
\hline 14 & $\begin{array}{l}\text { The video } \\
\text { project } \\
\text { made me } \\
\text { become } \\
\text { braver to } \\
\text { say what I } \\
\text { think. }\end{array}$ & $\begin{array}{r}77.4 \\
2\end{array}$ & 19.35 & 3.23 & $\begin{array}{c}4.0 \\
3\end{array}$ & 0.88 & High \\
\hline 15 & $\begin{array}{l}\text { The video } \\
\text { project } \\
\text { enabled me } \\
\text { to interact } \\
\text { more with } \\
\text { my friends } \\
\text { outside of } \\
\text { class. }\end{array}$ & $\begin{array}{r}80.6 \\
5\end{array}$ & 19.35 & 0.00 & $\begin{array}{c}4.1 \\
3\end{array}$ & 0.67 & High \\
\hline 16 & $\begin{array}{l}\text { I like the } \\
\text { fact that my } \\
\text { classmates } \\
\text { and I could } \\
\text { make the } \\
\text { decision on } \\
\text { how to do } \\
\text { the video } \\
\text { project. }\end{array}$ & $\begin{array}{r}87.1 \\
0\end{array}$ & 9.68 & 3.23 & $\begin{array}{c}4.3 \\
9\end{array}$ & 0.72 & High \\
\hline
\end{tabular}

Table 3. Cont

\begin{tabular}{|c|c|c|c|c|c|c|c|}
\hline 17 & $\begin{array}{l}\text { When there } \\
\text { was a } \\
\text { problem } \\
\text { while doing } \\
\text { the video } \\
\text { project, my } \\
\text { friends and } \\
\text { I could } \\
\text { solve it } \\
\text { together. }\end{array}$ & $\begin{array}{r}74.1 \\
9\end{array}$ & 22.58 & 3.23 & $\begin{array}{c}4.0 \\
3\end{array}$ & 0.84 & High \\
\hline 18 & $\begin{array}{l}\text { I learned } \\
\text { about my } \\
\text { English } \\
\text { ability from } \\
\text { my friends' } \\
\text { suggestions } \\
\text { while doing } \\
\text { the video } \\
\text { project. }\end{array}$ & $\begin{array}{r}70.9 \\
7\end{array}$ & 22.58 & 6.45 & $\begin{array}{c}3.9 \\
0\end{array}$ & 0.98 & High \\
\hline
\end{tabular}

In table 4.7 the means for the eight items in the questionnaire were high, ranging from 3.90 to 4.39 , reflecting the student participants' awareness of the importance of the ability to work with others as a team.

\section{3) Students' response toward technology used}

Utilizing technology for educational purposes does not come without complications. Students may find it terrifying or threatening. Therefore the students' responses toward technology used in student-made video project were investigated. It can be seen in the table 4 .

Table 4. Students' Responses toward Technology Used

\begin{tabular}{|c|c|c|c|c|c|c|c|}
\hline Item & Statement & $\begin{array}{c}\text { SA, } \\
\mathbf{A} \\
\%\end{array}$ & $\begin{array}{l}\mathbf{N} \\
\%\end{array}$ & $\begin{array}{c}\text { D, } \\
\text { SD } \\
\%\end{array}$ & $\begin{array}{c}\text { Mea } \\
\mathbf{n}\end{array}$ & $\begin{array}{c}\text { St } \\
\text { d. } \\
\text { De } \\
\text { v. }\end{array}$ & $\begin{array}{c}\text { Categ } \\
\text { ory }\end{array}$ \\
\hline 19 & $\begin{array}{c}\text { The video } \\
\text { project made } \\
\text { me improve my } \\
\text { computer skill. }\end{array}$ & $\begin{array}{r}80.6 \\
5\end{array}$ & $\begin{array}{r}19.3 \\
5\end{array}$ & $\begin{array}{r}0.0 \\
0\end{array}$ & 4.29 & $\begin{array}{r}0.6 \\
4\end{array}$ & High \\
\hline 20 & $\begin{array}{l}\text { Working with } \\
\text { technology } \\
\text { makes me } \\
\text { nervous } \\
\text { sometimes } \\
\text { because I'm } \\
\text { unfamiliar with } \\
\text { this kind of } \\
\text { activity. }\end{array}$ & $\begin{array}{r}77.4 \\
2\end{array}$ & $\begin{array}{r}19.3 \\
5\end{array}$ & $\begin{array}{r}3.2 \\
3\end{array}$ & 4.19 & $\begin{array}{r}0.6 \\
5\end{array}$ & High \\
\hline 21 & $\begin{array}{l}\text { I support the } \\
\text { use of } \\
\text { technology like } \\
\text { video project } \\
\text { for educational } \\
\text { purposes. }\end{array}$ & $\begin{array}{r}87.1 \\
0\end{array}$ & $\begin{array}{r}16.1 \\
3\end{array}$ & $\begin{array}{r}0.0 \\
0\end{array}$ & 4.28 & $\begin{array}{r}0.6 \\
7\end{array}$ & High \\
\hline
\end{tabular}


Table 4. Cont

\begin{tabular}{|c|c|c|c|c|c|c|c|}
\hline 22 & $\begin{array}{l}\text { More projects } \\
\text { with } \\
\text { technology } \\
\text { used should be } \\
\text { assigned for the } \\
\text { students to } \\
\text { improve our } \\
\text { digital literacy. }\end{array}$ & $\begin{array}{r}74.1 \\
9\end{array}$ & $\begin{array}{r}22.5 \\
8\end{array}$ & $\begin{array}{r}3.2 \\
3\end{array}$ & 4.00 & $\begin{array}{r}0.6 \\
8\end{array}$ & High \\
\hline 23 & $\begin{array}{l}\text { I want to } \\
\text { continue to do } \\
\text { similar project } \\
\text { involving } \\
\text { technology in } \\
\text { the future. }\end{array}$ & $\begin{array}{r}70.9 \\
7\end{array}$ & $\begin{array}{r}25.8 \\
1\end{array}$ & $\begin{array}{r}3.2 \\
3\end{array}$ & 4.09 & $\begin{array}{r}0.9 \\
1\end{array}$ & High \\
\hline
\end{tabular}

develop their computer skills in some manners throughout the student-made video project. Additionally they support the use of technology for additional purposes, and speak their agreement if more technology used is assigned for the students to improve the digital literacy as part of $21 \mathrm{st}$ century skills.

Moreover, despite the students' struggle to work with technology because they rarely involve in such kind of learning atmosphere previously, they wish to continue to do similar project involving technology in the future. It indicates whether the students did find a way to overcome their difficulties through group work or as the process continues they gradually gain their confidence and become familiar with technology.

\section{b. Qualitative Data}

The qualitative data was collected from interview and group observation checklist filled out by each group leader. Interview was done to gain deeper information in relation to the students' response toward student-made video project. While observation checklist and group reports were used to gain information in relation to their teamwork and their difficulties throughout the implementation of the project.

\section{Analysis of the Interview Data}

In the interview, the students' responses are mostly positive and thus supported the questionnaire results. Firstly, the students claimed that the course supported activeness and self-directedness in learning. The project made the students seek additional information independently outside the campus wall and trained them to be responsible for completing their

After examining the information gathered through the three different instruments - questionnaires, interview, and project work. They had self-evaluated their products, and sometimes they had to revise them several times.

Moreover, students described their work as an active process in which they edited and used materials and information from outside the school for their projects. They discussed multiple viewpoints when creating their digital stories. In the process, the students can find authenticity, connections to real life, and did the information searching and processing which eventually lead to knowledge creation.

Further, the students worked in groups with the aim that students would learn collaboration. Collaborative work requires that a group find methods of working effectively. The students reported that they had to set goals for their work, seek as a group how to complete their project, and make decisions on how to divide the project work. They also met challenges and tensions in the group. It was not always easy to overcome disagreements, but they also indicated that they learned to take the other group members' perspectives into consideration and found solutions to tensions. How to give and get feedback had been the most challenging task.

In addition, the students described what they had learned about technology in the student-made video project. Regarding the most important aspect they stressed that the project taught them to get and find help when they have technological problems. They explore the internet for the possible solutions. Digital literacy seems to be connected with collaboration and sharing. Students evaluated that studentmade video and video recording devices enhance students' learning. They described how they connected information searching from Internet with the video creation. When facing technical problems they had learnt to find answers online.

\section{Analysis of the Observation Checklist and Group} Reports Data

Despite the positive response, based on the observation checklist and group reports done by the group leader, the students still faced some anxieties and difficulties doing the project. The students who created the videos provided little criticism. The negative responses focused on lack of time, lack of technology skill, difficulty in memorizing the dialogues and inability to coordinate schedules with group members. It should be noted that prior experience with any outside student project, especially at a college that is heavily commuter rather than residential, will typically yield the same comments. Moreover, no other criticisms were provided among all respondents. Other information indicated that the teamwork were good for every group.

group observation checklist and group reports- the results can be summarized in the figure below. 


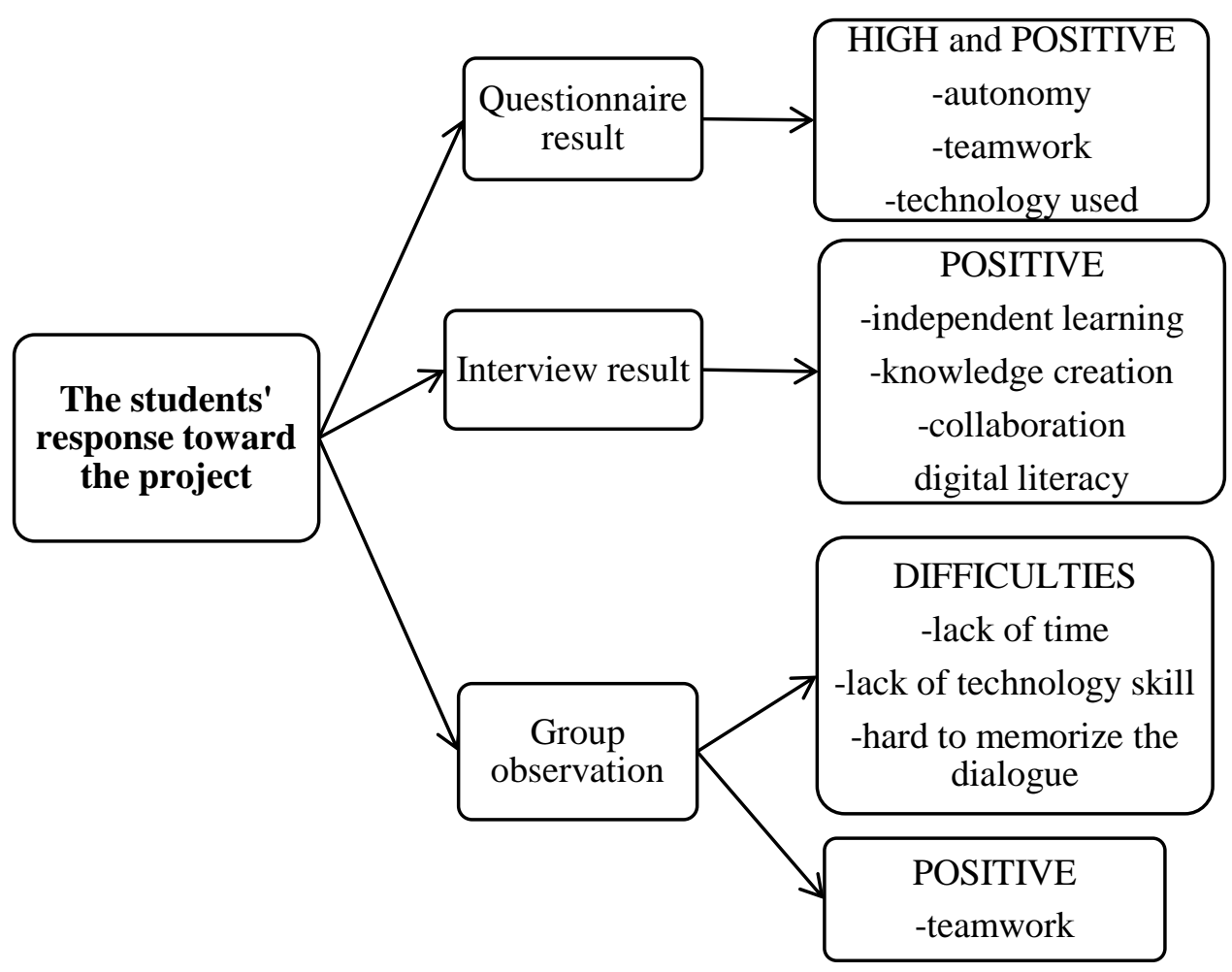

Figure 1. Summary of the Results

Based on the analysis of the data gathered from three instruments, it can be concluded that despite the students' difficulties in running the project, they positively responded to such kind of activity. They claimed that the project trained their independent learning, collaboration, and digital literacy skills.

Discussion

Among the benefits stated by the students were that the video project fostered students' ability to look for more knowledge and improve their English outside the classroom on their own time. As the students were compelled to complete their project, they became more independent and had to initiate activities by themselves outside the classroom. In other words, doing project work allowed the students to be more independent and in control. In addition to enabling them to be immersed in English to a greater degree, the project raised the students' confidence in using the language.

However, even though students realize the benefit of the video project, as seen in their responses in the questionnaire as well as from the interview sessions, the statements and high average score from the questionnaire do not suffice, as it can be argued that the student participants at the time of the responses were well aware that the project must be useful. This awareness may be due to the highly encouraged knowledge of English expressed by the instructor. Thus, the results are indicating the students' thoughts and beliefs rather than their emotional reaction to the project itself (Gardner, 2006).
It is important, therefore, to scrutinize further what the students associated with their positive attitudes as they answered the questions for this research, which will in turn lead to the knowledge of important factors to students' learning motivation.

Furthermore, apart from the students' perception and looking solely at the procedure of the project itself, when students are assigned project work to be completed on their own time and outside the classroom context, they are also given more freedom to create, improvise, and have a sense of ownership that traditional teacher-based classrooms do not have. As autonomy received the highest mean score (4.48) in the questionnaire for this study, being autonomous may be the most important reason for the participants' positive attitudes toward doing project work. This observation indicates that any classroom activity or assignment that incorporates autonomy may be highly welcome by students nowadays.

However, independence does not necessarily mean individual work. From the questionnaire and interview responses, working with others appeared to be another important issue pertaining to the video project for the students joining this research study. The students pointed out many benefits of teamwork: cooperating with friends, sharing what they knew and learning from them. As they work on the project, students are empowered as well as challenged to express, negotiate, and learn with their teammates. At the same time, they develop a sense of belonging in a team that can help each other select a topic and work toward accomplishing their mutual goal. As teens naturally feel 
comfortable with approval, reassurance, and solidarity, it can be argued that a sense of belonging in a group whose members support one another helped the student participants to enjoy doing project work more when compared to working in such an isolated environment as studying in a classroom.

Unfortunately, teamwork not only led to work improvement and self-development, it also caused a number of constraints to the completion of the project. In other words, working with others means having the same free time period to work together as well as the willingness to cooperate from all team members. When some members did not cooperatewhen there was only one member with video editing ability and he/she did not finish the work in time, for exampleworking in a team caused them a great amount of stress.

Even though the students had relatively high positive attitudes toward the video project, such stress on working and completing the project expressed by the students in the group observation and group reports as well should be taken into consideration. It is ironic that the very things that contribute to the fun of project work are the same things that caused them constraints. The obstacles mostly caused time conflicts, and social context. The social context is about how much they knew one another and how comfortable the students to one another. Unlike the students in the study by Greene and Crespi where the students were in the third and fourth years, most of the students in the present research were only beginning to know one another during that semester, making it more difficult to negotiate issues with group members when facing such problems and those concerning meeting deadlines [4]. Fortunately, despite all of these obstacles regarding teamwork, the students in general can overcome the situation as they gradually work together and get to know more of each other.

In addition, technology was also repeatedly viewed by the students as problematic, since not all of the students were good at using their computers to make videos. Therefore, in this study the researcher along with the research collaborator, blended the students who are expert in technological field with the average and beginner students. This resulting the positive responses from the students regarding the technology used in the project. Viewed from the responses, the students claimed to develop their computer skills in some manners throughout the student-made video project. Additionally they support the use of technology for additional purposes, and speak their agreement if more technology used is assigned for the students to improve the digital literacy as part of 21 st century skills

IV. CONCLUSION AND RECOMMENDATION

Based on the analysis of the data questionnaires, interview, and group observation checklist and group reports, it can be inferred that despite the students' difficulties in running the project, they positively responded to this activity. During the project, the students' soft skills and practical skills have developed in the aspecs of independent earning (autonomy), collaboration (teamwork), and digital literacy (technological skill) which are crucial parts of 21 st century skills.

\section{References}

[1] NCREL, \& Metiri Group. enGauge 21st century skills: Literacy in the digital age. Napierville, IL and Los Angeles, CA: NCREL and Metiri. 2003

[2] Puspa, Adelia. Student-Made Video Project to Enhance Students Learning Experience. Thesis. Print. 2016

[3]Silverman, F. Learning styles: District Administration. September. pp. 70-71. 2006.

[4] Greene, Henry and Cheryl Crespi. "The Value of Student Created Videos in the College Classroom": An Exploratory Study in Marketing and Accounting. International Journal of Arts and Sciences. 2012. Web. 27th September 2015. 